\title{
The effect of different storage times on the oxygen-carrying capacity of the exosomes of red blood cells
}

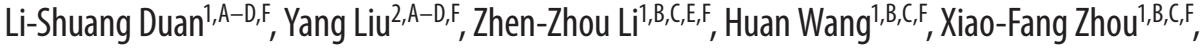

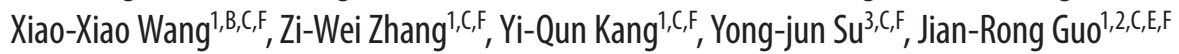 \\ ${ }^{1}$ Department of Anesthesiology, Shanghai Gongli Hospital, The Second Military Medical University, China \\ ${ }^{2}$ Ningxia Medical University, Gongli Hospital of Shanghai Pudong New Area Training Base, China \\ ${ }^{3}$ Department of Anesthesiology, Fujian Provincial Hospital South Branch, Fuzhou, China \\ A - research concept and design; $B$ - collection and/or assembly of data; $C$ - data analysis and interpretation; \\ $D$ - writing the article; $E$ - critical revision of the article; $F$ - final approval of the article
}

\section{Address for correspondence \\ Jian-Rong Guo \\ E-mail:jr_guo@yeah.net}

\section{Funding sources}

This work has been supported by the Key Disciplines Group Construction Project of Pudong Health Bureau of Shanghai (grant No. PWZxq2017-10) and National Natural Science Foundation of China (grant No. 81870147).

Conflict of interest

None declared

Received on June 2, 2020

Reviewed on June 3, 2020

Accepted on December 26, 2020

Published online on April 28, 2021

Cite as

Duan L-S, Liu Y, LiZZZ, et al. The effect of different storage times on the oxygen-carrying capacity of the exosomes of red blood cells. Adv Clin Exp Med. 2021;30(4):387-394. doi:10.17219/acem/131962

DOI

10.17219/acem/131962

\section{Copyright}

Copyright by Author(s)

This is an article distributed under the terms of the

Creative Commons Attribution 3.0 Unported (CC BY 3.0)

(https://creativecommons.org/licenses/by/3.0/)

\begin{abstract}
Background. After storing blood for a period of time, the structure and properties of the red blood cells $(\mathrm{RBC})$ will change, which results in a decrease in the oxygen-carrying capacity, and further has a certain impact on their exosomes.

Objectives. Effective oxygen uptake (Q), P50, 2,3-DPG, and $\mathrm{Na}^{+}-\mathrm{K}^{+}-\mathrm{ATP}$ of RBC after different storage times were detected. Electron microscopy was used to observe the morphology of RBC and the characteristics of secreting exosomes. Western blot was used to detect the expression of phenotypes CD63 and CD81 of exosomes, and the expression of mitochondrial riboprotein MRPS35 of exosomes was also detected to explore the mechanism of decreased function of RBC with the extension of preservation time.
\end{abstract}

Materials and methods. After the RBC suspension was prepared, the effective oxygen-carrying capacity (Q) and P50, as well as 2,3-DPG and Na ${ }^{+}-K^{+}-$ATP were prepared. This was followed by morphology observation of erythrocyte exosomes using transmission electron microscope (TEM), and by western blot analysis of exosome phenotypes CD63 and CD81.

Results. Erythrocytes secrete exosomes, which results in abnormal expression of related proteins in mitochondria. This leads to increased ROS production, mitochondrial apoptosis and, finally, changes in or damage to erythrocytes.

Conclusions. Changes in the rheological properties and oxygen-carrying functions of erythrocytes during preservation are all observable manifestations, and underlying these manifestations are mechanisms of damage to erythrocytes at a molecular level. Erythrocytes secrete exosomes, which results in abnormal expression of related proteins in mitochondria, increasing ROS production, mitochondrial apoptosis and, finally, changes or damage to erythrocytes.

Key words: exosomes, red blood cells, storage time, oxygen-carrying capacity 


\section{Background}

Blood is a fluid tissue composed of blood cells and plasma. Its main physiological functions include transporting oxygen, nutrients and metabolites for tissues and organs of the body. The body takes the oxygen needed for metabolism from the atmosphere through breathing and expels carbon dioxide produced by metabolism. In the human body, the respiratory process includes 3 processes that are conducted at the same time, namely, external respiration, transportation of gas in blood and internal respiration, while red blood cells ( $\mathrm{RBC}$ ) are the main means of gas transportation. ${ }^{1}$ The amount of oxygen physically dissolved in the blood only accounts for $1.5 \%$ of the total oxygen and $98.5 \%$ of oxygen is transported by binding to the hemoglobin of $\mathrm{RBC} .^{2}$ In a sense, $\mathrm{RBC}$ are able to distinguish active and inactive cells that take part in metabolism and release oxygen to active cells.

In modern medicine, it is very common therapeutic practice to transfer blood or blood components to patients, which can increase blood volume and plasma protein, improve circulation, change blood composition, and improve blood oxygen-carrying capacity. Due to the widespread using of blood transfusion in clinical practice, the function of blood preservation has been reconsidered. The structure and properties of RBC will change and their oxygen-carrying capacity will decrease after preservation for a period of time. However, the influence of changes in oxygen-carrying capacity on their erythrocyte exosomes has not been reported.

\section{Objectives}

Our research aimed to detect some relative parameters of oxygen-carrying activity and exosomes of erythrocyte storing in different storage time to explore the mechanism of erythrocyte function decline.

\section{Materials and methods}

\section{Materials}

Flow meter (Changzhou Chengfeng Flow Meter Company, Changzhou, China); pressure gauge (Yangquan Precision Instrument Factory, China); Cy-3 digital oxygen analyzer (Shanghai Huaguang Instrument Factory, Shanghai, China); BC-2800 blood count instrument (Mindray Medical International, Shenzen, China); $37^{\circ} \mathrm{C}$ constant temperature water bath (GSY-II; Beijing Medical Equipment Factory, Beijing, China); low speed M109077 automatic centrifuge (Zhongxi, Shanghai, China); $200 \mathrm{~L}$ and 1000 L samplers (Eppendorf, Hamburg, Germany); AB fresh/frozen plasma and defoaming agent were donated from blood bank; 2,3-DPG detection kit (Wuhan Huamei
Biotechnology Company, Wuhan, China); $\mathrm{Na}^{+}-\mathrm{K}^{+}$-ATPase assay kit (Nanjing Jiancheng Biological Company, Nanjing, China); rabbit anti-human CD63 antibody, rabbit anti-human CD81 antibody (System Biosciences, Palo Alto, USA); H7600 transmission electron microscope (TEM) (Hitachi, Tokyo, Japan); and exosome extraction kit (Sigma-Aldrich, St. Louis, USA).

\section{Preparation of RBC suspension}

A total of $400 \mathrm{~mL}$ whole blood were collected from 5 healthy blood donors and all blood samples were examined to confirm that they accord with the national blood and component blood quality requirements. ${ }^{3}$ When they passed the examination and conformed to the operation procedures of blood station technical operation regulations (2012 edition), the blood samples were prepared into suspended RBC. ${ }^{4}$ Suspended RBC were divided into 5 empty bags using sterile bonder, and named 1 day group, 7 day group, 14 day group, 21 day group, and 28 day group. Q, P50, 2,3-DPG and $\mathrm{Na}^{+}-\mathrm{K}^{+}$-ATP in suspension of RBC and whole blood were observed. This research has been authorized for ethical review by hospital committees, and all volunteers agree to sign the informed consent.

\section{Measurement of effective oxygen-carrying capacity (Q) and P50}

The blood samples were centrifuged with $3696 \times \mathrm{g} / \mathrm{min}$ at $4^{\circ} \mathrm{C}$ for $10 \mathrm{~min}$ after conventional anticoagulant treatment. Then plasma was removed and CPDA-1 erythrocyte preservation fluid was added to prepare suspended RBC. Suspended RBC coming from the same patient were divided into 5 copies and restored at $4^{\circ} \mathrm{C}$. The blood samples were tested at 1, 7, 14, 21, and 28 days. Arterial oxygen partial pressure was simulated under the following test conditions: $\mathrm{O}_{2}=16 \mathrm{~mL} / \mathrm{min}, \mathrm{CO}_{2}=3 \mathrm{~mL} / \mathrm{min}$, $\mathrm{N}_{2}=120 \mathrm{~mL} / \mathrm{min}$, flow rate: $100 \mathrm{~mL} / \mathrm{min}, 37^{\circ} \mathrm{C}$ to sample inflatable for $9 \mathrm{~min}$. Finally, $1 \mathrm{~mL}$ of the sample was extracted for blood gas analysis. The charging conditions were adjusted to $\mathrm{O}_{2}=6 \mathrm{~mL} / \mathrm{min}, \mathrm{CO}_{2}=3 \mathrm{~mL} / \mathrm{min}$, $\mathrm{N}_{2}=160 \mathrm{~mL} / \mathrm{min}$, and the flow rate was $100 \mathrm{~mL} / \mathrm{min}$. Samples were inflated for $6 \mathrm{~min}$ at $37^{\circ} \mathrm{C}$ after being balaced for $10 \mathrm{~min}$. Finally, $1 \mathrm{~mL}$ of the sample was also extracted for sexual blood gas analysis. According to the calculation formula of effective oxygen-carrying capacity of erythrocytes, $\mathrm{Q}=20 \times(\mathrm{S} 1-\mathrm{S} 2)$. When the oxygen partial pressure rose to $100 \mathrm{~mm} \mathrm{Hg}$ (pulmonary arterial partial oxygen pressure) and stabilized, the oxygen saturation of hemoglobin in the solution was measured and recorded as $\mathrm{S} 1$. When the oxygen partial pressure of mixed gas was $40 \mathrm{~mm} \mathrm{Hg}$ (oxygen partial pressure of pulmonary venous blood), the oxygen saturation of hemoglobin was measured and recorded as S2. P50 value was calculated according to the blood gas analysis results when the oxygen partial pressure reached $100 \mathrm{~mm} \mathrm{Hg.}{ }^{5}$ 


\section{Measurement of 2,3-DPG and $\mathrm{Na}^{+}-\mathrm{K}^{+}-\mathrm{ATP}$}

Suspended erythrocytes obtained from 1 patient were divided into 5 portions and measured at $1,7,14,21$, and 28 days according to the 2,3-DPG and $\mathrm{Na}^{+}-\mathrm{K}^{+}$-ATP kit instructions. ${ }^{6}$

\section{Morphology observation of erythrocyte}

Morphology of erythrocytes was characterized on $\mathrm{H} 7600$ TEM at $0,7,14,21$, and 28 days after the storage of erythrocytes.

\section{Observation of erythrocyte exosomes}

\section{Extraction of exosomes}

RBC solution ( $1 \mathrm{~mL}$ ) was put into a centrifuge tube and $7.5 \mathrm{~mL}$ of phosphae-buffered saline (PBS) was added. Organelles were removed after centrifuging for $30 \mathrm{~min}$ at $10,000 \times \mathrm{g}$ at $4^{\circ} \mathrm{C}$. Then, supernatant was centrifuged and concentrated by using a $100 \mathrm{kDa}$ Millipore ultrafiltration centrifugal pipe (Merck Millipore, Burlington, USA) at $1000 \times \mathrm{g}$ at $4^{\circ} \mathrm{C}$ for $30 \mathrm{~min}$. The concentrate was filtered with $0.22 \mu \mathrm{m}$ according to operating instructions for tissue culture medium and precipitation liquid was added into the supernatant in a proportion of $5: 1$ at $4^{\circ} \mathrm{C}$ overnight for precipitation $(>12 \mathrm{~h})$. Exosome suspension was obtained after centrifuging at $1000 \times \mathrm{g}$ at $4^{\circ} \mathrm{C}$ for $30 \mathrm{~min}$ and stored at $-80^{\circ} \mathrm{C}$.

\section{Morphology observation of exosome with TEM}

One drop of erythrocyte exosomes suspended in PBS was taken and dropped onto the copper sample carrier network with a diameter of $2 \mathrm{~nm}$. After staying at room temperature for $2 \mathrm{~min}$, the edge liquid was gently absorbed with filter paper. Then, $3 \%$ phosphotungstic acid solution ( $\mathrm{pH}=6.8)$ was retained at room temperature for $5 \mathrm{~min}$. The morphology of exosomes was observed using TEM.

\section{Western blot analysis of exosome phenotypes CD63 and CD81}

\section{Extraction of exosome protein}

The PBS resuspended exosomes were mixed with RIPA at a ratio of 1:1 according to an appropriate volume, and then the exosomes were allowed to rest on ice to shake violently for $1 \mathrm{~min}$. This procedure was repeated 5 times to fully crack the exosomes. The concentration of exosome protein was determined using BCA method and a third volume of $4 \times$ SDS buffer was added to samples, which were boiled at $100^{\circ} \mathrm{C}$ for $5 \mathrm{~min}$ and preserved at $-80^{\circ} \mathrm{C}$.

\section{Western blot analysis of protein CD63 and CD81}

SDS-PAGE was prepared with a concentration of 10$12 \%$, and the sample was loaded at a total protein mass of $50 \mu \mathrm{g}$ per well. SDS-PAGE was performed at a voltage of $80 \mathrm{~V}$ and $100 \mathrm{~V}$ for the laminated and separated gels, respectively. The protein was transferred to polyvinylidene fluoride (PVDF) membrane after electrophoresis under $350 \mathrm{~mA}$ constant current condition for $2 \mathrm{~h}$. The PVDF membrane was incubated shaking for $1 \mathrm{~h}$ in $5 \%$ skimmed milk, then rabbit anti-human CD81 antibody (1:500) or CD63 antibody $(1: 500)$ were added to incubate at $4^{\circ} \mathrm{C}$ overnight. The film was washed 3 times with $1 \times$ Trisbuffered saline with Tween (TBST). Horseradish peroxidase (HRP)-labeled rabbit anti-sheep (1:1500) was added to incubate at $37^{\circ} \mathrm{C}$ for $1 \mathrm{~h}$. The film was washed 5 times with $1 \times$ TBST and exposed to analysis. ${ }^{8}$

\section{Western blot}

Western blot was used to detect MRPS35 expression. A total of $40 \mu \mathrm{g}$ protein were extracted from each cell, analyzed using 10\% SDS-PAGE and transferred to nitrocellulose membrane. With sealing fluid containing $5 \%$ skimmed milk powder, the membrane was incubated at $37^{\circ} \mathrm{C}$ for $1 \mathrm{~h}$, then MRPS35 antibodies $(1: 500)$ were added to incubate at $4^{\circ} \mathrm{C}$ overnight. After enhanced chemiluminescence (ECL) developing, the gray value was analyzed using the analysis system of electrophoresis gel imaging.

\section{Statistical analysis}

All data were processed using the SPSS v. 19.0 statistical software (IBM Corp., Armonk, USA) and expressed as mean \pm standard deviation (SD). A paired t-test was performed to compare the 2 groups. Statistical significance was defined as $\mathrm{p}<0.05$.

\section{Results and discussion}

\section{Effective oxygen-carrying capacity and P50}

Effective oxygen-carrying capacity (Q) of whole blood and $\mathrm{RBC}$ suspensions had declined with the enhancement of storage time, as shown in Table 1. Figure 1A shows that Q decreased sharply in the first 14 days and gently after further 14 days. The Q of suspension RBC decreased by $54.4 \%$ at 14 days and $62.7 \%$ at 28 days, while that of whole blood decreased by $39.1 \%$ at 14 days and $52.1 \%$ at 28 days. P50 of RBC decreased gradually as the storage days increased as shown in Fig. 1B. It shows that the P50 of suspension RBC decreased by $11.6 \%$ at 14 days and $25.1 \%$ at 28 days. Whole blood P50 was reduced by $16.1 \%$ at 14 days and $28.6 \%$ at 28 days. 
A

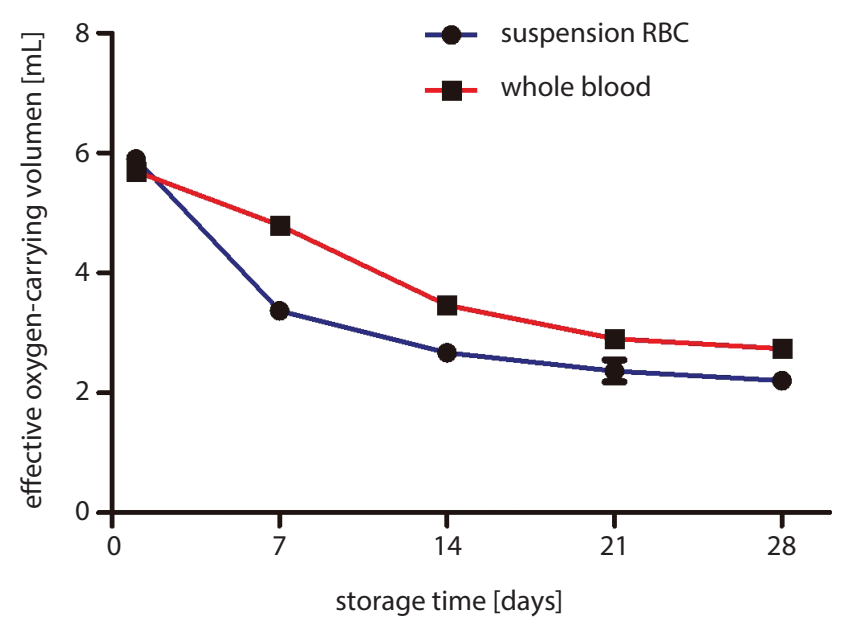

B

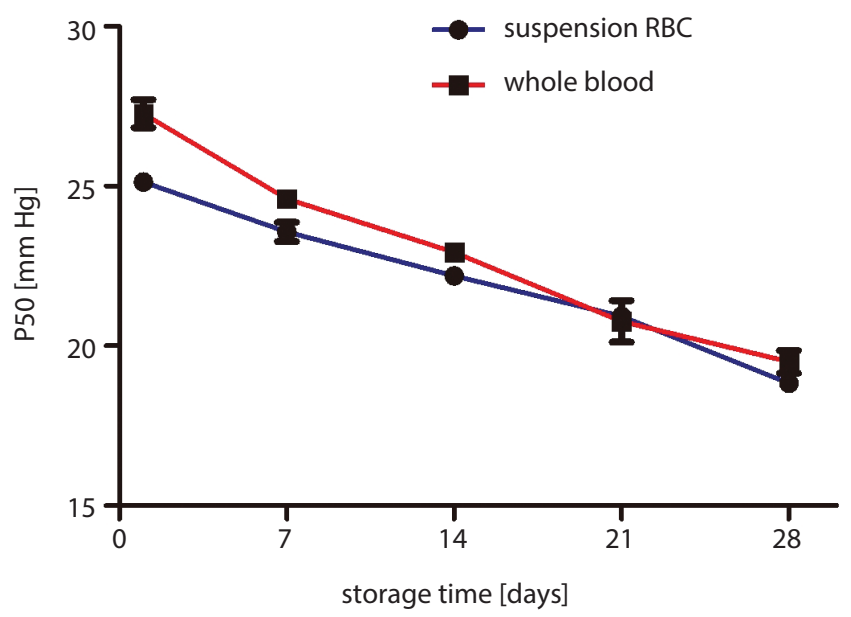

Fig. 1. Changes in oxygen-carrying capacity in whole blood and suspension RBC

A - effective oxygen-carrying volume of whole blood and suspension RBC; B - P50 of whole blood and suspension RBC.

Table 1. Changes of RBC oxygen-carrying capacity at different storage time

\begin{tabular}{|l|c|c|c|c|c|}
\hline \multicolumn{1}{|c|}{ Group } & $(\mathrm{d})$ & 1 & $\mathbf{7}$ & 14 & $\mathbf{2 1}$ \\
\hline \multirow{2}{*}{ Whole blood } & $\mathrm{Q}[\mathrm{mL}]$ & $5.70 \pm 0.08$ & $4.80 \pm 0.08$ & $3.47 \pm 0.12$ & $2.90 \pm 0.08$ \\
\hline \multirow{2}{*}{ Suspension RBC } & $\mathrm{P} 50[\mathrm{~mm} \mathrm{Hg}]$ & $27.3 \pm 0.6$ & $24.6 \pm 0.4$ & $22.9 \pm 0.3$ & $2.73 \pm 0.12$ \\
\hline & $\mathrm{Q}[\mathrm{mL}]$ & $5.90 \pm 0.08$ & $3.37 \pm 0.12$ & $2.67 \pm 0.12$ & $2.37 \pm 0.26$ \\
\hline
\end{tabular}

Hamasaki et al. ${ }^{9}$ first used the method of measuring Q to evaluate the change of erythrocyte oxygen-carrying capacity. They found that $\mathrm{Q}$ had a linear relationship with storing time and gradually declined with the enhancement of storage time. The lower the P50, the greater the affinity between RBC and oxygen, and the greater the ability to bind with oxygen, which is not conducive to oxygen release. ${ }^{10}$ It can be demonstrated from the results of decreased Q and P50 that the ability of releasing oxygen of RBC was also decreased.

\section{2,3-DPG and $\mathrm{Na}^{+}-\mathrm{K}^{+}-\mathrm{ATP}$}

At the first 14 days, the concentration of 2,3-DPG in RBC declined sharply and then leveled off after 14 days. The data showed that it decreased by $63.0 \%$ at the $7^{\text {th }}$ storage day and by $91.7 \%$ at the $14^{\text {th }}$ storage day (Table 2 ). The concentration of 2,3-DPG in whole blood gradually decreased with the increase of storage days, which was not as dramatic as that of RBC (Fig. 2A). The concentration of $\mathrm{Na}^{+}-\mathrm{K}^{+}-\mathrm{ATP}$ in erythrocytes decreased gently in the first 7 days, and then decreased sharply from 7 to 14 days. The concentration of $\mathrm{Na}^{+}-\mathrm{K}^{+}$-ATP decreased by $53.8 \%$ in 7 days after storage and $69.5 \%$ in 14 days after storage. The concentration of $\mathrm{Na}^{+}-\mathrm{K}^{+}$-ATP in the whole blood decreased by $41.2 \%$ after 7 days and by $63.3 \%$ after 14 days (Fig. 2B).

2,3-DPG is the unique glycolytic intermediate of RBC, which can reduce the affinity between hemoglobin and oxygen, and is one of the important factors to regulate the physiological function of oxygen transport in the body. In some physiological and pathological conditions, such as mountaineering, plateau, anemia and congenital heart disease, the level of 2,3-DPG in RBC is significantly increased to compensate for the ability of hemoglobin to release oxygen for tissue metabolism. On the contrary, in some pathological conditions, the decreased content of 2,3-DPG is not conducive for utilization of oxygen in tissue cells, such as acidosis or shock. ${ }^{11,12}$ The lower content of 2,3-DPG makes it difficult to release oxygen, which indicated that the oxygen-carrying capacity of RBC is decreased and the physiological function of $\mathrm{RBC}$ is variable.

Red blood cells regulate cell volume mainly by regulating intracellular $\mathrm{Na}^{+}$and $\mathrm{K}^{+}$content through membrane $\mathrm{Na}^{+}-\mathrm{K}^{+}$-ATP, and maintaining this function requires about $30 \%$ of RBC's ATP production. ${ }^{13,14} \mathrm{Na}^{+}-\mathrm{K}^{+}$-ATP changes its conformation through phosphorylation and dephosphorylation, which lead to changes in its affinity with $\mathrm{Na}^{+}$ and $\mathrm{K}^{+}$. The role of "sodium-potassium pump" is to maintain cell permeability and cell volume. ${ }^{15,16}$ Under normal physiological conditions, $\mathrm{Na}^{+}(1.0-2.0 \mathrm{mmol} / \mathrm{L})$ in $\mathrm{RBC}$ was slightly higher than $\mathrm{K}^{+}(0.8-1.5 \mathrm{mmol} / \mathrm{L})$ when it was passively transported into the cytoplasm. Both the increase of $\mathrm{Na}^{+}$and the decrease of $\mathrm{K}^{+}$in $\mathrm{RBC}$ can activate $\mathrm{Na}^{+}-$ $\mathrm{K}^{+}$-ATP. $\mathrm{Na}^{+}-\mathrm{K}^{+}$-ATP is involved in the active transmembrane transport of $\mathrm{Na}^{+}$and $\mathrm{K}^{+}$inside and outside the cell to maintain the balance of ions. ${ }^{17} \mathrm{Na}^{+}-\mathrm{K}^{+}$-ATP also plays 
A

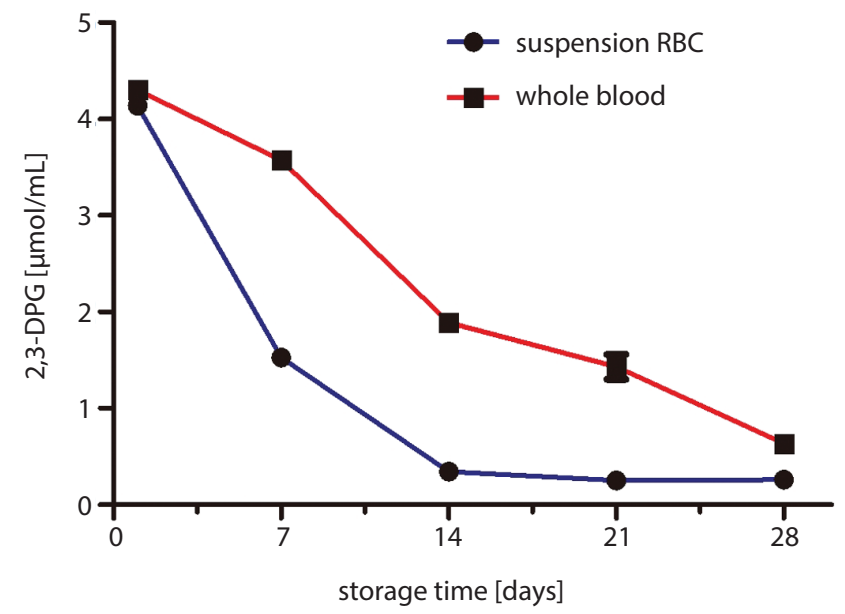

B

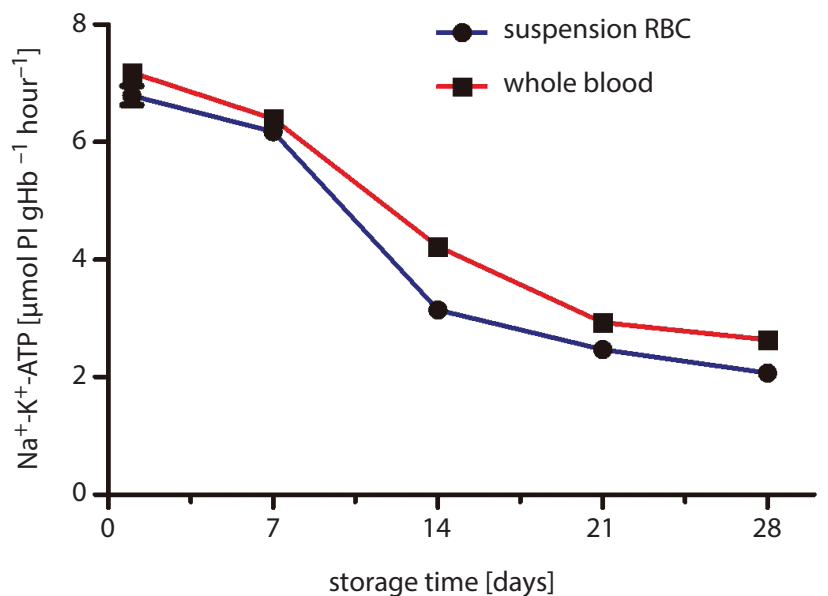

Fig. 2. Changes in 2,3-DPG, $\mathrm{Na}^{+}-\mathrm{K}^{+}-\mathrm{ATP}$ in $\mathrm{RBC}$ and whole blood in different storage times

A - the concentration of 2,3-DPG; B - the content of $\mathrm{Na}^{+}-\mathrm{K}^{+}-\mathrm{ATP}$.

Table 2. Changes of erythrocyte oxygen-carrying capacity at different storage time

\begin{tabular}{|c|c|c|c|c|c|c|}
\hline (d) & Group & 1 & 7 & 14 & 21 & 28 \\
\hline 2,3-DPG [umol/mL] & suspension RBC & $4.14 \pm 0.07$ & $1.53 \pm 0.03$ & $0.34 \pm 0.02$ & $0.25 \pm 0.02$ & $0.26 \pm 0.01$ \\
\hline 2,3-DPG $[\mu \mathrm{mol} / \mathrm{mL}]$ & whole blood & $4.3 \pm 0.07$ & $3.57 \pm 0.11$ & $1.89 \pm 0.10$ & $1.43 \pm 0.18$ & $0.63 \pm 0.10$ \\
\hline $\mathrm{Na}^{+}-\mathrm{K}^{+}-\mathrm{ATP}\left[\mu \mathrm{mol}\right.$ PI.gHb-1 hour $\left.{ }^{-1}\right]$ & suspension RBC & $6.79 \pm 0.23$ & $6.17 \pm 0.04$ & $3.14 \pm 0.06$ & $2.47 \pm 0.08$ & $2.07 \pm 0.03$ \\
\hline $\mathrm{Na}^{+}-\mathrm{K}^{+}-\mathrm{ATP}\left[\mu \mathrm{mol} \mathrm{Pl} . \mathrm{gHb}^{-1}\right.$ hour $\left.^{-1}\right]$ & whole blood & $7.18 \pm 0.12$ & $6.39 \pm 0.04$ & $4.22 \pm 0.13$ & $2.93 \pm 0.07$ & $2.63 \pm 0.07$ \\
\hline
\end{tabular}

an important role in maintaining the normal morphology of cells, and the survival of RBC depends on the energy provided by ATP. ${ }^{18}$ However, decreased activity of $\mathrm{Na}^{+}-$ $\mathrm{K}^{+}$-ATP will reduce the release of ATP energy and affect the normal metabolism of RBC.

\section{Observation of erythrocyte morphology}

The first 14 days of storage were characterized by cell morphology, defined as double concave disc, thick edge, round or oval, nucleate-free, dense, and with a diameter of 15-25 $\mu \mathrm{m}$. The number of cells decreased after 14 days, and the TME images of RBC at storage days 21 and 28 were sparse and irregular. Therefore, the storage time has a certain effect on the morphology of erythrocytes, which can further cause the decline of erythrocyte function and increased damage (Fig. 3).

\section{Observation of exosomes in RBC}

As it can be seen from the electron microscope images, the particle size of the material ranges from 30 to $100 \mathrm{~nm}$ and the morphology is vesicular. After 7 days of storage, in the electron micrograph, exosomes appeared as black spots as shown in Fig. 4. The black spots gradually increased after 14 days and increased more by the $14^{\text {th }}$ and $21^{\text {st }}$ days. These 2 time points showed the most number and clearest exosome morphology.
Previous studies have confirmed that the vesicles in vivo are divided into 3 categories: 1) vesicles released by apoptosis with micron-scale particle sizes; 2) vesicles formed by budding of the cell membrane, with particle sizes of several hundred nanometers; 3 ) exosomes, with micron-scale particle size below $100 \mathrm{~nm}$. Therefore, we believed that the vesicles in TEM images were exosomes.

\section{Western blot analysis of protein CD63 and CD81}

Western blot analysis probing for 2 exosome marker proteins, CD81 and CD63, was performed. As shown in Fig. 5, both CD63 and CD81 proteins were absent or hardly detectable in the isolated vesicles at a storage time of 7 days, but the expression of CD63 and CD81 proteins could be clearly detected at a storage time of 14 days. Western blot analysis probing for 2 exosome marker proteins, CD81, CD63, and MPRS35 were performed, as shown in Fig. 5 and Fig. 6. The increased expression of CD81/CD63 protein indicates that exosomes secreted were increased by RBC.

Minetti et al. ${ }^{19}$ discovered a membranous vesicle from the culture medium of reticulocyte. These vesicles were exosomes, and many kinds of cells could secrete exosomes under normal and pathological conditions. The exosomes were discoid vesicles with a diameter of 40-100 nm, which were mainly derived from polyvesicles formed by intracellular lysosomal microparticles, and these were released into 

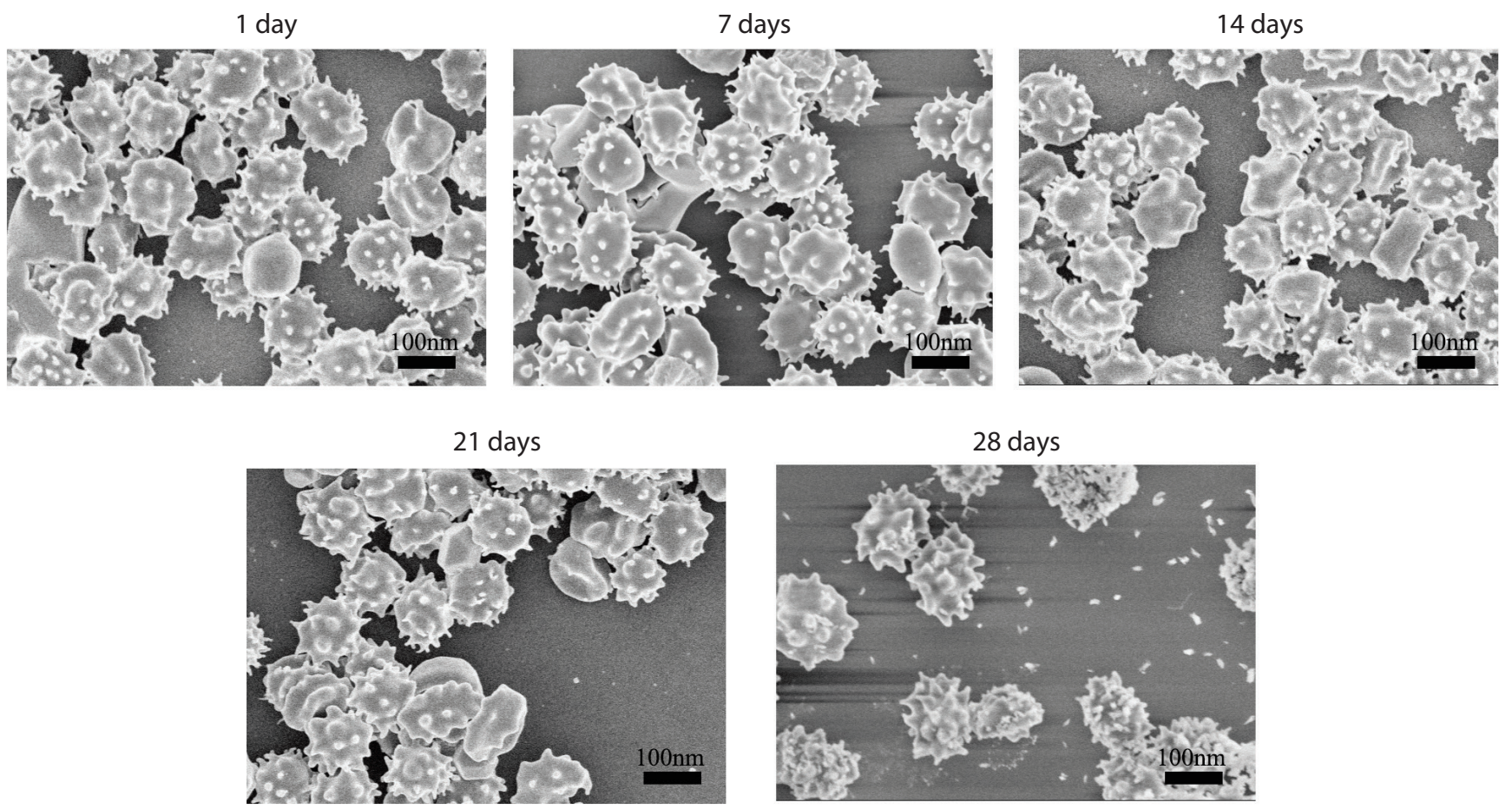

Fig. 3. Changes in erythrocyte morphology after different storage times. The scale bar was $100 \mathrm{~nm}$

1 day

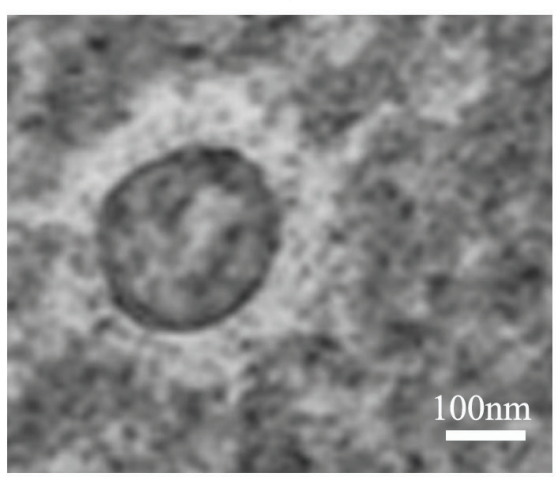

21 days

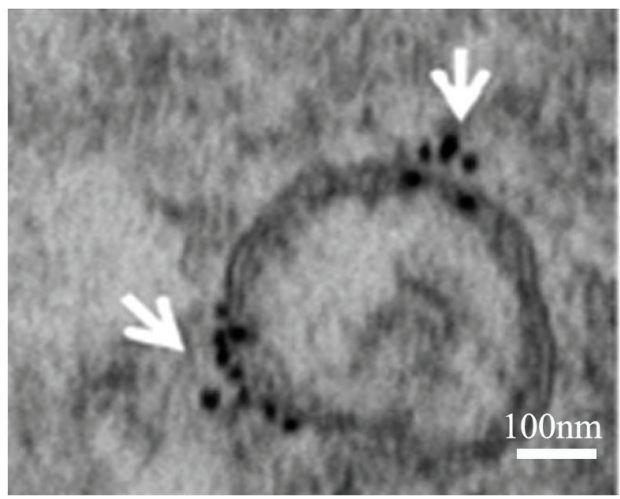

7 days

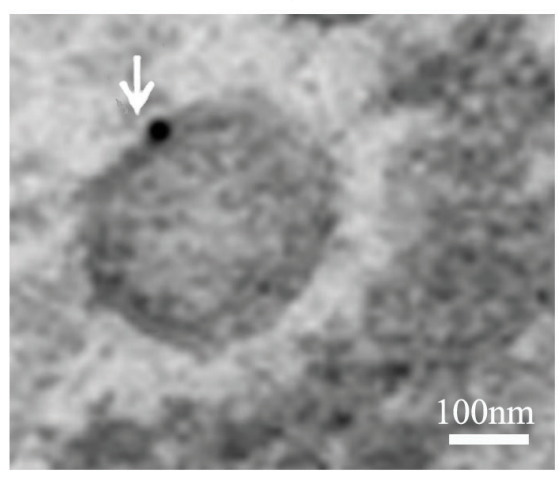

14 days

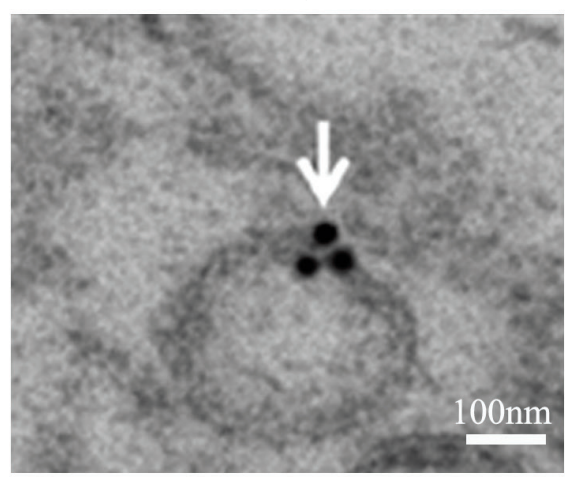

28 days

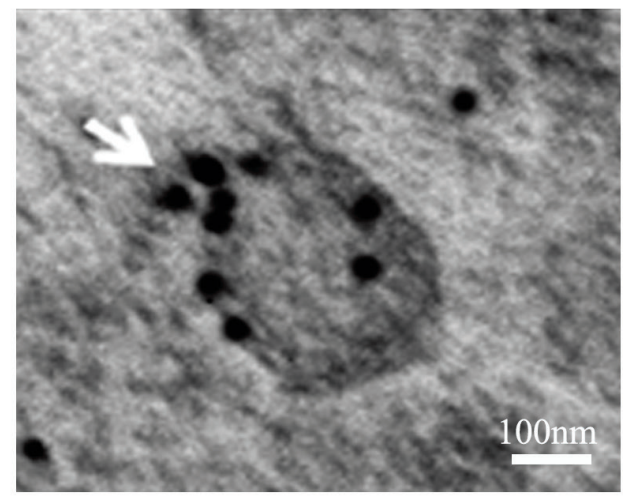

Fig. 4. TEM imaging of exosome in RBC in different storage times. Exosome was marked with arrow. The scale bar was $100 \mathrm{~nm}$

the extracellular matrix after the fusion of the extracellular membrane of polyvesicles with the cell membrane. Exosomes were identified as nano-level vesicles secreted by living cells, and included proteins, nucleic acids, metabolites and other components from the mother cells. They not only carried the information of the mother cells, but also directly or indirectly regulated the functions and phenotypes of the receiving cells. ${ }^{20}$ Exosomes played an important role 


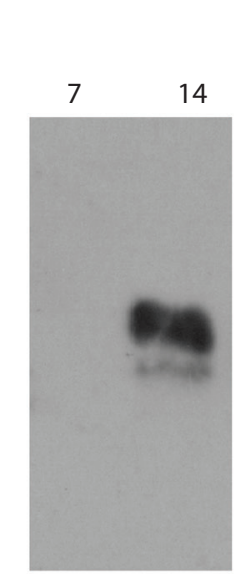

CD63

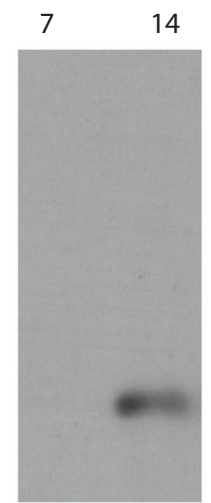

CD81

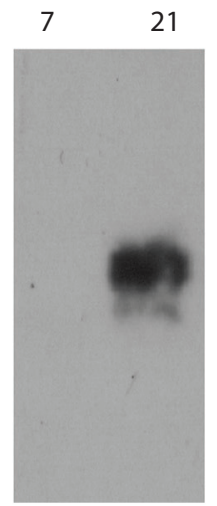

CD63

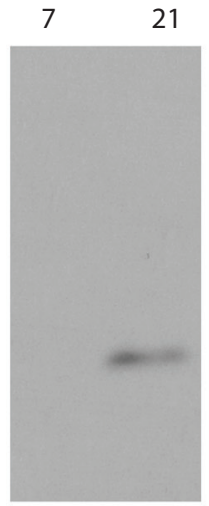

CD81

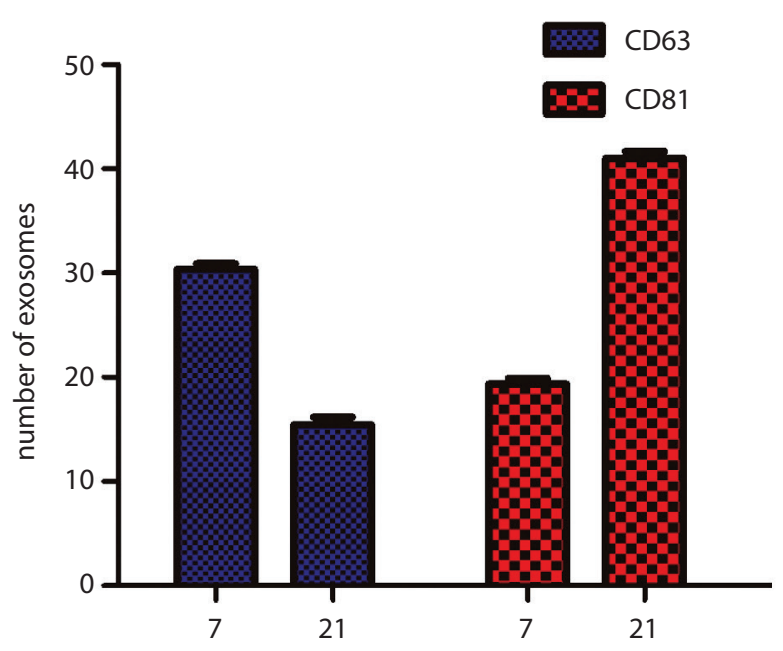

Fig. 5. Western blot analysis of expression levels of exosome-associated proteins CD63 and CD81
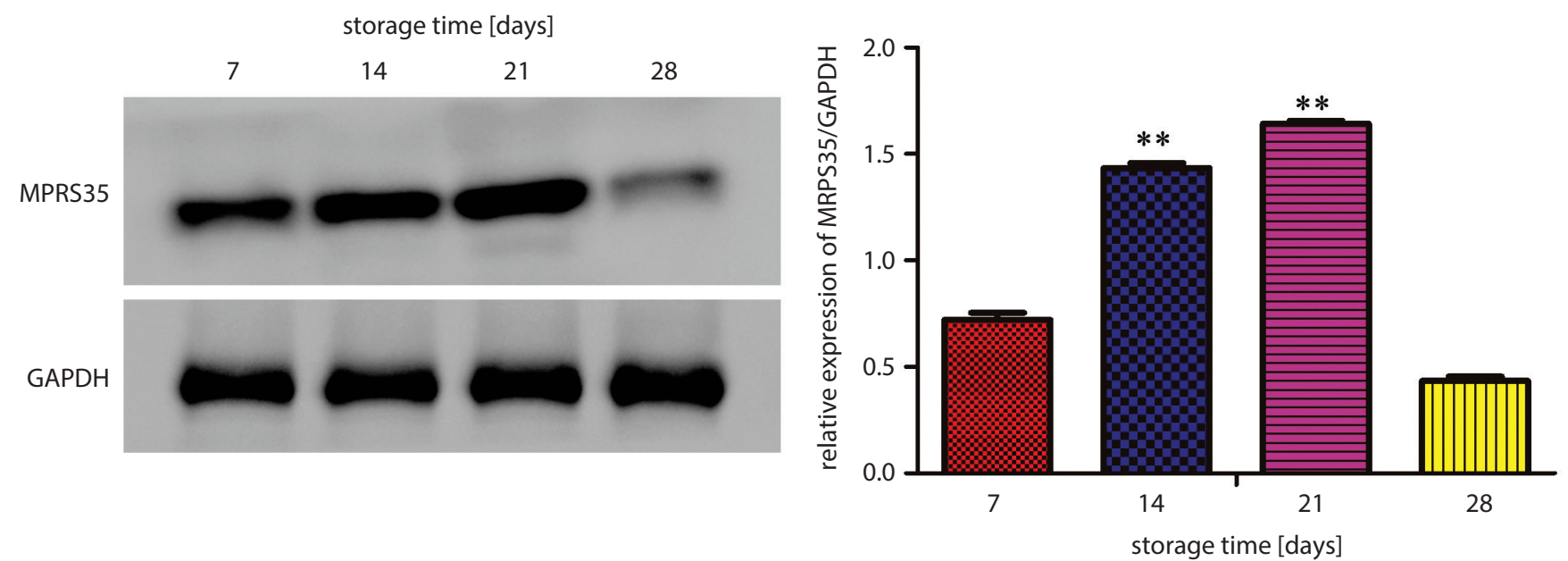

Fig. 6. Protein level of MRPS35 in RBC after different storage times, determined with western blotting ( $\mathrm{mean} \pm \mathrm{SD}, \mathrm{n}=3 .{ }^{* *} \mathrm{p}<0.01$ compared to 7 days group)

in immunopathology, such as antigen presentation, tumor growth and migration, tissue damage repair etc. Exosomes played an irreplaceable role in signal transduction in vivo, and also played an extremely important role in numerous physiological and pathological processes, including cardiovascular diseases, ${ }^{21}$ nervous system diseases, ${ }^{22,23}$ and therapy. ${ }^{24,25}$ Meanwhile, exosomes secreted by different cells had different components and functions, which could be used as biomarkers for disease diagnosis.

\section{Western blot analysis of exosome protein MRPS35 expression}

The expression of MRPS35 increased from the $7^{\text {th }}$ day to the $21^{\text {st }}$ day after storage, and the relative expression of MRPS35 was significantly different from that at the storage time of day 14 and day 21 . However, the expression of MRPS35 in erythrocyte mitochondria was significantly reduced at the storage time of 28 days. Abnormal expression of MRPS35 protein can induce apoptosis of normal cells. Relevant studies have proved that MRPS35 is a key protein which affects mitochondrial function, and plays a very important role in the occurrence of apoptosis. Mitochondria are an important organelle in eukaryotic cells. They can provide ATP which are the main source of energy and heat for life by oxidative phosphorylation of the electron transport chain in their inner membrane. In addition, mitochondria also played a key role in the process of apoptosis regulation. The abnormal expression of MRPS35 can make the mitochondrial electron transport barriers, and induce the production of free radicals increases, which leads to mitochondrial structure and function damage and the decrease of membrane potential, further to activate mitochondrial mediated apoptosis pathway and accelerate the apoptosis of RBC.

\section{Conclusions}

Changes in the rheological properties and oxygen-carrying functions of erythrocytes during the preservation process are manifestations, and underlying these manifestations are mechanisms of damage to erythrocytes at a molecular level. 


\section{ORCID iDs}

Li-Shuang Duan (1) https://orcid.org/0000-0002-5111-058X Yang Liu (1) https://orcid.org/0000-0003-4743-1193 Zhen-Zhou Li (1) https://orcid.org/0000-0003-4306-2036 Huan Wang (1) https://orcid.org/0000-0001-8785-6124 Xiao-Fang Zhou (10) https://orcid.org/0000-0002-4241-0521 Xiao-Xiao Wang (1) https://orcid.org/0000-0003-4764-2281 Zi-Wei Zhang (1) https://orcid.org/0000-0002-2140-4886 Yi-Qun Kang (10) https://orcid.org/0000-0002-5717-4576 Yong-jun Su (D) https://orcid.org/0000-0003-3600-3361 Jian-Rong Guo (1) https://orcid.org/0000-0002-1759-6619

\section{References}

1. Yoshida T, Prudent M, D'Alessandro A. Red blood cell storage lesion: Causes and potential clinical consequences. Blood Transfus. 2019; 17(1):27-52. doi:10.2450/2019.0217-18

2. Shah A, Brunskill SJ, Desborough MJ, Doree C, Trivella M, Stanworth SJ. Transfusion of red blood cells stored for shorter versus longer duration for all conditions. Cochrane Database Syst Rev. 2018;12(12):Cd0 10801. doi:10.1002/14651858.CD010801.pub3

3. Lagerberg JW, Salado-Jimena JA, Löf H, et al. Evaluation of the quality of blood components obtained after automated separation of whole blood by a new multiunit processor. Transfusion. 2013;53(8): 1784-1807. doi:10.1111/trf.12010

4. Pasqualetti D, Ghirardini A, Arista MC, et al. Blood component fractionation: Manual versus automatic procedures. Transfus Apher Sci. 2004;30(1):23-28. doi:10.1016/j.transci.2003.07.002

5. Timmerman LA, Holton T, Yuneva M, et al. Glutamine sensitivity analysis identifies the $\mathrm{xCT}$ antiporter as a common triple-negative breast tumor therapeutic target. Cancer Cell. 2013;24(4):450-465. doi:10.1016/j.ccr.2013.08.020

6. Aktaran Bala $D$, Ozcan M. The effects of freezing on long-term storage of canine erythrocytes. Pol J Vet Sci. 2016;19:401-406. doi:10. 1515/pjvs-2016-0050

7. Mao JH, Liang ZF, Tian YQ, et al. Effects of different states of $p 53$ on the exosomes secreted by mouse bone marrow mesenchymal stem cells. Journal of Jiangsu University. 2017;27:103-106. http://en.cnki.com.cn/ Article_en/CJFDTotal-ZJYZ201702003.htm

8. Klymiuk MC, Balz N, Elashry MI, Heimann M, Wenisch S, Arnhold S. Exosomes isolation and identification from equine mesenchymal stem cells. BMC Vet Res. 2019; 15(1):42-49. doi:10.1186/s12917-019-1789-9

9. Hamasaki N, Yamamoto M. Red blood cell function and blood storage. Vox Sang. 2000;79(4):191-197. doi:10.1159/000056729

10. Dinkla S, Peppelman M, van der Raadt J, Atsma F. Phosphatidylserine exposure on stored red blood cells as a parameter for donor-dependent variation in product quality. Blood Transfus. 2014;12(2):204-209. doi:10.2450/2013.0106-13

11. Xiong $Y$, Xiong $Y$, Wang $Y$, et al. Exhaustive-exercise-induced oxidative stress alteration of erythrocyte oxygen release capacity. Can J Physiol Pharmacol. 2018;96(9):953-962. doi:10.1139/cjpp-2017-0691

12. Luisada-Opper AV. Colorimetric determination of 2,3-diphosphoglycerate in whole blood. Clin Chem. 2020;19(1):118-120. PMID:4683355
13. Cetinkaya CD, Gurbilek M, Koc M. Evaluation of the relationship of erythrocyte membrane $\mathrm{Na}^{+} / \mathrm{K}^{+}$-ATPase enzyme activity and tumor response to chemoradiotherapy in patients diagnosed with locally advanced nonsmall cell lung cancer and glioblastoma multiforme. J Cancer Res Ther. 2018;14(9): 450-457. doi:10.4103/jcrt.JCRT_675_15

14. Deryugina AV, Boyarinov GA, Simutis IS, Nikosiskiy VO. Correction of metabolic indicators of erythrocytes and myocardium structure with ozonized red blood-cell mass. Cell Tissue Biol. 2018;12(3): 207-212. doi:10.1134/S1990519X18030033

15. Mackay A, Davies DL, Horton PW. Is thallium-201 of use in the measurement of total exchangeable potassium in man? Eur J Clin Invest. 2008;8(4):261-262. https://doi.org/10.1111/j.1365-2362.1978.tb00863.x

16. Patrick J. The relationship between intracellular and extracellular potassium in normal and malnourished subjects as studied in leukocytes. Pediatr Res. 1978;12(7):767-770. doi:10.1203/00006450-19780 7000-00005

17. Yi J, Zhang XQ, Mu SJ. Effects of high dose rate and low dose radiation on human erythrocyte atpase. Clinical Blood Transfusion and Examination. 2009;11:25-26. doi:10.1016/j.ijrobp.2009.07.1273

18. Dai XF, Huang SF; Clinical Laboratory Department. Relevant research on potassium in plasma and erythrocyte,blood $\mathrm{pH}$, and enzymatic activity of $\mathrm{Na}^{+}-\mathrm{K}^{+}-$ATP in patients with hypokalaemic periodic paralysis. China Modern Medicine. 2013;31:29-31.

19. Minetti G, Achilli C, Perotti C, Ciana A. Continuous change in membrane and membrane-skeleton organization during development from proerythroblast to senescent red blood cell. Front Physiol. 2018; 9:286. doi:10.3389/fphys.2018.00286

20. Li D, Ren H, Liu C, Wang F, Zhang L. A study on the invention and experiments of a new type of blood preservation liquid. Chin J Blood Transfus. 2013;09:841-842. doi:10.1016/j.ijpe.2014.12.013

21. Ong SG, Lee WH, Huang M, et al. Cross talk of combined gene and cell therapy in ischemic heart disease: Role of exosomal micro-RNA transfer. Circulation. 2014;130(11 Suppl 1):S60-69. doi:10.1161/CIRCU LATIONAHA.113.007917

22. Haney MJ, Klyachko NL, Zhao Y, et al. Exosomes as drug delivery vehicles for Parkinson's disease therapy. J Control Release. 2015;207:1830. doi:10.1016/j.jconrel.2015.03.033

23. Yuyama K, Sun H, Mitsutake S, Igarashi Y. Sphingolipid-modulated exosome secretion promotes clearance of amyloid-beta by microglia. J Biol Chem. 2012;287(14):10977-10989. doi:10.1074/jbc.M111.324616

24. Zhang L, Zhang S, Yao J, et al. Microenvironment-induced PTEN loss by exosomal microRNA primes brain metastasis outgrowth. Nature. 2015;527(7576):100-104. doi:10.1038/nature15376

25. Yuan FL, Wu QY, Miao ZN, et al. Osteoclast-derived extracellular vesicles: Novel regulators of osteoclastogenesis and osteoclast-osteoblasts communication in bone remodeling. Front Physiol. 2018;30:1-6. doi:10.3389/fphys.2018.00628

26. Bardyn M, Rappaz B, Jaferzadeh K, et al. Red blood cells ageing markers: A multi-parametric analysis. Blood Transfus. 2017;15(3):239-248. doi:10.2450/2017.0318-16

27. Kim JK, Park J-H, Han S-B, Cho IY, Jang K-M. Allogeneic blood transfusion is a significant risk factor for surgical-site infection following total hip and knee arthroplasty: A meta-analysis. J Arthroplasty. 2017;32(1):320-325. doi:10.1016/j.arth.2016.08.026 